\title{
EFFECT OF SUBSTITUTION OF BARLEY GRAINS BY DISCARDED DATES ON REPRODUCTIVE PERFORMANCE OF NEW ZEALAND WHITE RABBIT DOES
}

\author{
Walaa A. Salama; Marwa A. Suliman; M.A. El-Shora and A.I. Abd-El- Lateif \\ Animal Production Research Institute, Agricultural Research Center, El-Dokki, Giza, Egypt. \\ Corresponding author: Walaa A. Salama, E-mail: Address: walaa.attia2@gmail.com
}

(Received 27/10/2015, accepted 5/1/2016)

\section{SUMMARY}

$\mathrm{T}$ he study was designed to investigate the reproductive performance of rabbit does fed different levels of discarded dates. The discarded dates were gathered, sun-dried and ground by hammer mill for proximate analysis and feed formulation. Four experimental diets were formulated to supply $18 \%$ crude protein and $2500 \mathrm{Kcal} \mathrm{DE} / \mathrm{kg}$. First diet was control, while discarded dates replaced barely grains at 25,50 , and $75 \%$ for the other three diets. A total number of 20 New Zealand White (NZW) rabbit does about 5 months of age, weighing about $2.827 \pm 20.10 \mathrm{~kg}$ were randomly distributed into 4 experimental treatments (5 does/ treatment). Productive performance, blood constituents, thyroid activity, progesterone hormone assay and economic of efficiency were measured. Results indicated that: The gestation length, total feed intake, daily feed intake, mating weight, gestation and suckling weight, change in weight during gestation and suckling periods and total milk yield were not significantly affected $(\mathrm{P} \leq 0.05)$ by different treatments. The Litter weight at birth and kid weight at weaning were significantly increased $(\mathrm{P} \leq 0.05)$ for rabbits fed diets with $25 \%$ discarded dates as well as litter weight at weaning and kid weight at birth were significantly increased $(\mathrm{P} \leq 0.05)$ with rabbits fed diets containing 25 and $50 \%$ discarded dates. The catalase activity was significantly increased with rabbits fed diets containing discarded dates at levels 50 and $75 \%$. Also, there were significantly decrease of glucose and lipid peroxides with rabbits fed diets containing discarded dates at $75 \%$ compared to those fed control diets. Progesterone hormone was significantly increased for rabbits fed diets with $25 \%$ discarded dates. Moreover, total trioiodothyronine values $\left(\mathrm{T}_{3}\right)$ were significantly increased with rabbits fed diets containing 25 and 50\% discarded dates compared with control group. However, total thyroxin $\left(\mathrm{T}_{4}\right)$ was not affected by different treatments. The groups fed the diets with $75 \%$ discarded dates achieved the highest economical efficiency followed by those fed diet contained $50 \%$ discarded dates. It was therefore concluded that discarded dates as source of energy could replace $75 \%$ of barely grains in the diets of rabbit does without adverse effect on their reproductive performance.

Keywords: rabbits; does; litter size; litter weight; discarded dates; milk yield; energy source

\section{INTRODUCTION}

Nowadays, rabbit farming is becoming more and more attractive to many animal breeders due to its high fecundity, high mothering ability, adaptability to a wide range of conditions, high genetic variability, high roughage utilization and low cost of production (Zarrouki et al., 2004). The economical efficiency of a rabbitry depends mainly upon the reproductive performance of the doe, which in turn is affected by their fertility and prolificacy (Castellini et al., 2003). Female reproduction is more interesting and attractive subject to study and preferred by many researchers and this is essential and more important and beneficial for successful rabbit breeding. Litter size, birth weight and conception rate are so important economic traits in any productive animal. The nutritional factors are one of these important factors which affect the economical intensive rabbit production, under the sub-tropical conditions of Egypt. The price of the main ingredients in poultry and rabbits diets is constantly growing. So, new unconventional local sources of low price ingredients need to be identified and validated. The feed cost of animal nutrition represents more than $70 \%$ of the total production cost. It is now urgent to look for alternative feedstuffs to compensate the high cost of the conventional feedstuffs. Rabbits are herbivores and consume high fiber diets. $\mathrm{T}$ he digestive strategy of rabbits for the utilization of fibrous diets was described by Cheeke (1982). Grains, i.e. corn, barley, sorghum and oats are the primary courses of high energy feed for 


\section{Salama et al.}

livestock. Barley grains are the most important sources as carbohydrates for rabbit diets. Because of the shortage and high price of barley grains, one of the alternatives to solve this problem is using nonconventional ingredients as a partial replacement of barley grains in rabbit diets.

Dates (Phoenix dactylifera L.) are very popular in most of the Middle Eastern countries. Over $70 \%$ of the total world production are produced in this area and are considered an important national crop in some Arabian countries. A considerable amount $(20 \%)$ of produced dates is inedible and is not beneficial for human consumption due to their poor quality. Dates are very rich in saccharides, their total sugars may reach up to $87 \%$ in the tamr stage and the monosaccharides content are mainly $44 \%$ glucose and $50 \%$ fructose and some other sucrose (Sawaya et al., 1983). Date fruit can provide $2.67 \mathrm{Mcal} / \mathrm{kg}$ of digestible energy. Dates contain approximately $78.5 \%$ dry matter, $2.2 \%$ crude protein, $0.5 \%$ fat, $2.3 \%$ crude fiber, $72.9 \%$ carbohydrate and $1.9 \%$ ash, so it can supply $87 \%$ of the digestible energy provided by the same unit of traditional grain feed (Alkhateeb and Ali-Dinar, 2001). Dates contain many important vitamins and minerals and their mineral content in dried dates can vary from 0.1 to $916 \mathrm{mg} / 100 \mathrm{~g}$ of date flesh (Khan et al., 2008). Dates contain high levels of selenium, copper, potassium, and magnesium, in addition to moderate concentrations of manganese, iron, phosphorus, and calcium and small quantities of boron (Barreveld, 1993).

Palm fruit has high content of phytonutrients with antioxidant properties. So, there is possibility that palm fruit offers some health advantages by reducing lipid oxidation, oxidative stress and free radical damage (Wattanapenailboon and Wahlqvist, 2003) For this reason, dates that are not suitable for human consumption are considered a good source of energy for animals and poultry.

In addition, significant amounts of cull dates (which are unstable for human consumption) are available in Egypt which can be utilized as a cheap non-conventional ingredient in rabbit diets. The annual production of dates in Egypt is estimated by 1.113.270 ton (FAO, 2011). Moreover, the quantity of cull dates is estimated by about $20 \%$ of all dates produced (Al-Yousef et al., 1994). AL-Dobaib et al., (2009) found no significant differences in milk yield from goats does fed diet with $30 \%$ discarded dates. El-Shora et al., (2014) found that yield as actual milk were higher $(\mathrm{P}<0.05)$ for cows fed $66 \%$ discarded dates than those of control. Cows fed $66 \%$ discarded dates recorded the highest $(\mathrm{P}<0.05)$ percentages of fat, protein, and total solids in milk.

It has been found that published researches regarding use of discarded dates in rabbit does diets are limited almost, there is no available data on the effect of discarded dates on the reproductive performance of the rabbits. Therefore, the present study aimed to investigate the effect of partial replacement of barely grains by discarded dates on reproductive performance, and economical efficiency of New Zealand White (NZW) rabbit does.

\section{MATERIALS AND METHODS}

This study was carried out at Poultry Research Station, in Kafr EL- Sheikh Governorate, Animal Production Research Institute, Agricultural Research Center, Ministry of Agriculture, Egypt. Discarded dates were obtained from Luxor Governorate, Egypt, and were ground by hammer mill and kept for chemical analysis before mixing into the experimental diets.

\section{The experimental design}

In this study, four experimental diets were formulated; the first used as control diet without discarded dates while the other three diets were containing discarded dates at 7.80, 15.60 or $23.40 \%$ levels in the diet replacing (25, 50 or $75 \%$ of barely grains) of rabbit does diets as shown in Table (1). A total number of 20 New Zealand White (NZW) does aged 5 months, weighing about $2.827 \pm 20.10 \mathrm{~kg}$ were randomly distributed individually into 4 experimental treatments (5 does/ treatment). Does were housed separately in individual wired-cages as replicates. Mating was achieved by 4 adult New Zealand White bucks aged 6 months with $3.0 \mathrm{~kg}$ average body weight, with good fertility records. Bucks were fed ad-libtum on the gestating control diet. All animals were kept under the same management system and provided with fresh water and pelleted diets, ad-libtum all over the experimental period under natural light system. All the experimental diets were formulated to be iso-nitrogenous and iso-caloric, and to meet all the essential nutrient requirements of rabbit does according to NRC (1977). The chemical analysis of the experimental samples of diets, discarded dates and barely grains were done according to the conventional methods of A.O.A.C (2000). Chemical analyses of discarded dates and barely grains are presented in Table (2). The digestible energy (DE kcal $/ \mathrm{kg}$ ) of discarded dates and barely grains were calculated according to the equation of 
Cheeke (1987). Amount of feed consumed was calculated weekly. Gestation length was calculated as period between kindling and post partum. The change in live body weight during gestation period was calculated as the difference between the live body weight at kindling and body weight at post partum, while the change in live body weight during suckling was calculated as the difference between the live body weight at the end of suckling period (at weaning) and the body weight at post partum, in which the kids became four weeks of age.

Table (1). Ingredients and chemical composition of experimental diets (on DM basis).

\begin{tabular}{|c|c|c|c|c|}
\hline \multirow{2}{*}{ Ingredient } & \multirow{2}{*}{ Control } & \multicolumn{3}{|c|}{ Discarded dates } \\
\hline & & $25 \%$ & $50 \%$ & $75 \%$ \\
\hline Soybean meal (44\% CP) & 21.00 & 22.00 & 23.50 & 25.00 \\
\hline Discarded dates & ----- & 7.80 & 15.60 & 23.40 \\
\hline Barely grains & 31.20 & 23.40 & 15.60 & 7.80 \\
\hline Wheat bran & 13.90 & 13.90 & 13.90 & 13.90 \\
\hline Clover hay & 27.15 & 26.15 & 24.65 & 23.15 \\
\hline Lime stone & 0.70 & 0.70 & 0.70 & 0.70 \\
\hline Di calcium phosphate & 2.20 & 2.20 & 2.20 & 2.20 \\
\hline Sodium Chloride $(\mathrm{NaCl})$ & 0.30 & 0.30 & 0.30 & 0.30 \\
\hline Vit.\& min. $\mathrm{Mix}^{1} *$ & 0.30 & 0.30 & 0.30 & 0.30 \\
\hline DL-Methionine & 0.20 & 0.20 & 0.20 & 0.20 \\
\hline Anticoccidia (Diclazuril) & 0.05 & 0.05 & 0.05 & 0.05 \\
\hline Molasses & 3.00 & 3.00 & 3.00 & 3.00 \\
\hline Total & 100 & 100 & 100 & 100 \\
\hline \multicolumn{5}{|l|}{ Chemical analysis $\%$} \\
\hline DM\% & 89.40 & 88.90 & 90.20 & 90.74 \\
\hline \multicolumn{5}{|c|}{ Chemical analysis\% (on DM basis) } \\
\hline OM\% & 89.79 & 89.57 & 88.95 & 88.35 \\
\hline $\mathrm{CP} \%$ & 18.50 & 18.30 & 18.25 & 18.20 \\
\hline $\mathrm{CF} \%$ & 12.79 & 12.90 & 12.87 & 12.85 \\
\hline $\mathrm{EE} \%$ & 2.14 & 2.25 & 2.38 & 2.46 \\
\hline NFE\% & 56.36 & 56.12 & 55.45 & 54.84 \\
\hline Ash $\%$ & 10.21 & 10.43 & 11.05 & 11.65 \\
\hline$* * \mathrm{DE} \mathrm{kcal} / \mathrm{kg}$ & 2527.24 & 2523.69 & 2524.66 & 2525.30 \\
\hline \multicolumn{5}{|l|}{ Calculated analysis $\%$} \\
\hline Calcium & 1.249 & 1.246 & 1.236 & 1.228 \\
\hline Total phosphorus & 0.849 & 0.830 & 0.810 & 0.792 \\
\hline Methonine & 0.467 & 0.477 & 0.489 & 0.502 \\
\hline Lysine & 0.979 & 1.03 & 1.09 & 1.15 \\
\hline
\end{tabular}

$* * D E(k c a l / g)=4.36-0.0491 * N D F$, Where $N D F \%=28.924+0.657 * C F \%$ according to Cheeke (1987)

The milk yield of each doe was recorded at the $7^{\text {th }}, 14^{\text {th }}, 21^{\text {st, }} 28^{\text {th }}$ days after kindling using the weightsuckle-weight technique described by McNitt and Lukefahr (1990). In this method, the kids of each doe were separated from their dams by closing the gates between the nest box, and the doe's cage was allowed to suckle them by opening the gate. In the next morning, the members of each litter were weighed (in grams) and returned again to the nest box, and the doe to suckle them by opening the gate. The litter after suckling was weighed again and milk yield was determined and recorded as the difference in the weight pre-and post suckling. Weekly milk yields ( at 7 days (MY7), 14 days (MY14), 21 days (MY21) and 28 days (MY28) were calculated as the mean of milk amount estimated in this week, and them multiplied by 7 to get the weekly milk yield. Total milk yield (TMY) of the first three weeks of suckling (TMY 21) was calculated as the mean of the milk amount of each week multiplied by 3 to get 


\title{
Salama et al.
}

the total milk yield from birth up to 21 days. Body weight and weight gain of kids were measured at birth and at weaning. Mortality rate (MR) for kids during lactation were calculated as:

\author{
MR of kids = \\ Number of the kids born alive - Number of the kids at weaning \\ Number of the kids born alive \\ X 100
}

\section{Blood parameters}

Individual blood samples were taken at 9.00 am from the marginal ear vein and collected in $5 \mathrm{ml}$. heparinized test tubes and centrifuged at 3000 r.p.m for 20 minutes then plasma were transferred and stored in deep freezer at approximately $-20^{\circ} \mathrm{C}$ till the time of chemical analysis. Chemical analyses of the blood plasma were carried out for quantity determination of blood as total protein (Gornal et al., 1949), albumin (Doumas and Waston, 1971), transaminases (AST, aspartate aminotransferase and ALT alanine aminotransferase, Reitman and Frankel, 1957), Catalase (Aebi, 1984), Glucose (Trinder, 1969), Lipid Peroxides (Malondialdehyde), (Satoh, 1978), plasma progesterone (Bojanic et al., 1991) The concentrations of triiodothyronine (T3, ng/ml) and thyroxin $(\mathrm{T} 4, \mathrm{ng} / \mathrm{ml})$ in plasma were determined according to Barker and Silverton (1982) by using commercial kits supplied by Monobind Inc.

The economical efficiency of experimental diets was calculated as the ratio between net revenue and cost of feed consumed according to Soliman et al. (2012).

Data from all response variables were analyzed using General Linear Models (GLM) procedure of SAS Institute (2004).The statistical model used was:

$$
\mathrm{Yij}=\mu+\mathrm{T} i+\mathrm{eij}
$$

Where: $\mu=$ overall mean of $\mathrm{Yij}, \mathrm{Ti}=$ effect of treatment, $\mathrm{i}=(1, \ldots, 4)$, eij $=$ experimental random error. Variables having a significant F-test were compared using Duncan's multiple range test (Duncan, 1955).

\section{RESULTS AND DISCUSSION}

\section{Chemical composition:}

As shown in Table (2), chemical analyses of discarded dates compared with barely grains revealed that, CP was (5.12 vs. 12.40), CF (9.18 vs. 5.72), EE (4.43 vs. 2.60), NFE (67.73 vs. 76.74), ash (13.54 vs. 2.54) and DE (2647 vs.2758). In this respect, Abd el-Rahman et al. (2012) found that cull dates contain 87.15 4.89, 3.60, 3.34 and 10.23\% as DM, CP, CF, EE and ash, respectively. AL-Dobaib et al. (2007) found that discarded dates contained CP (3.8\%), CF (2.8\%), EE (3.4\%) ash (10.4\%), Calcium(0.17) and phosphorus $(0.03 \%)$.

Table (2). Chemical composition of discarded dates and barely grains (on DM basis).

\begin{tabular}{lllllllll}
\hline \multirow{2}{*}{ Item } & \multicolumn{7}{c}{ Chemical analysis\% } & (on DM basis) \\
\cline { 2 - 8 } & DM\% & OM\% & CP\% & CF\% & EE\% & NFE\% & Ash\% & *DE (Kcal/kg) \\
\hline $\begin{array}{l}\text { Discarded } \\
\text { dates }\end{array}$ & 85.26 & 86.46 & 5.12 & 9.18 & 4.43 & 67.73 & 13.54 & 2643.89 \\
$\begin{array}{l}\text { Barely } \\
\text { grains }\end{array}$ & 88.20 & 97.46 & 12.40 & 5.72 & 2.60 & 76.74 & 2.54 & 2755.50 \\
\hline DE (kcal/g) = 4.36-0.0491x NDF, Where NDF\% & $28.924+0.657 x$ CF\% & according to Cheeke (1987).
\end{tabular}

\section{Performance of rabbit does during gestation period:}

The gestation length, total feed intake, daily feed intake, mating weight, gestation weight and the change in body weight doe at mating and kindling are presented in Table (3). Results showed that gestation length, total feed intake, daily feed intake, mating weight, gestation weight and the change in body weight doe at mating and kindling were not affected significantly $(\mathrm{P} \leq 0.05)$ by different treatments. Values of daily feed intake for does fed diets discarded dates were ranged between 162.66 to $177.33 \mathrm{~g}$ vs. $154.56 \mathrm{~g} /$ day for the control diet. Change in weight were ranged between +135.00 to $+148.00 \mathrm{~g}$ vs. 
$+113.00 \mathrm{~g}$ for the control diet. Mating weight were between 2817.00 to $2851.00 \mathrm{~g}$ vs. $2808.00 \mathrm{~g}$ for the control diet. Gestation weight recorded 2979, 2965.00 and $2986.00 \mathrm{~g}$ with groups fed 25, 50 and $75 \%$ discarded dates, respectively versus $2921.00 \mathrm{~g}$ for those fed control diet. The regular increase in body weight at this phase could be due to the active growth of the embryos at this stage. These results revealed that does can tolerate using discarded dates in the diet up to $75 \%$ substitution for barely grains during the gestation period (30 days) without adverse effects. In this respect, Defang et al. ( 2012) observed no significant difference $(\mathrm{P}>0.05)$ for mating weight, gestation weight, average weight gain, feed consumption during gestation period and gestation length with rabbit fed diets containing $100 \%$ sweet potato concentrate meal instead of maize. Ajayi et al. (2005) found that change in body weights of the rabbit does did not differ during gestation period when rabbit doe were fed un autoclaved maize-milling waste at levels 25, 50 and 75\%. However, significant differences $(\mathrm{P}<0.05)$ were observed in does relative change in body weight during gestation period when rabbit does were fed autoclaved maize-milling at levels 25, 50 and 75\% compared to control group. The consumption of dates by women human before and after delivery can act as a tonic to strengthen the uterine muscles. Dates not only help in activating the delivery process but may also prevent the post delivery bleeding due to the presence of some constricting substances (Ali et al., 2013)

Table (3). Performance traits of rabbit does as affected by different treatments during gestation period.

\begin{tabular}{lllccc}
\hline \multirow{2}{*}{ Item } & \multirow{2}{*}{ Control } & \multicolumn{4}{c}{ Discarded dates \% } \\
\cline { 3 - 5 } & & $25 \%$ & $50 \%$ & $75 \%$ & SEM \\
\hline Gestation length (days) & 30.33 & 30.00 & 30.33 & 30.00 & 0.21 \\
Total feed intake( kg/doe) & 4.688 & 5.320 & 5.283 & 4.880 & 0.18 \\
Daily feed intake (( kg/doe) & 154.56 & 177.33 & 174.18 & 162.66 & 6.47 \\
Mating weight* $(\mathrm{g})$ doe & 2808.00 & 2833.00 & 2817.00 & 2851.00 & 20.10 \\
Gestation weight** $(\mathrm{g})$ doe & 2921.00 & 2979.00 & 2965.00 & 2986.00 & 20.93 \\
Change in weight*** $(\mathrm{g})$ & +113.00 & +146.00 & +148.00 & +135.00 & 15.45 \\
\hline
\end{tabular}

Difference within the same row were not significantly different $(p \leq 0.05)$.

*Mating weight $(g)$ doe is live body weight at post partum.

**Gestation weight $(g)$ doe is live body weight at kindling.

$* * *$ Change in weight $(g)=$ Gestation weight $(g)$ - Mating weight $(g)$.

\section{Performance of rabbit does during suckling period:}

Results in Table (4) indicated that total feed intake, daily feed intake, suckling weight, change in weight of the doe between kindling and weaning of kids and total milk yield were not significantly affected by the different treatments. Daily feed intake was ranged between 222.82 to $245.89 \mathrm{~g}$ vs. 217.50 $\mathrm{g} /$ day for the control diet. Feed intake recorded highest value with rabbits fed $25 \%$ discarded dates diet followed by rabbits fed diets containing 50 and $75 \%$. While, the lowest value was occurred with rabbits fed control diet. Feed intake increased with discarded dates may be due to the positive palatability effect of dates. However, feed intake decrease with increasing levels of dates may due to increase of neutral detergent fiber (NDF) and acid detergent fiber (ADF) by increased dates in diets. This interpretation is in accordance with Khattab (2013) who stated that increased neutral detergent fiber (NDF) and acid detergent fiber in sheep diets with increasing levels of dates led to decrease intake of OM and NFE in sheep. Change in weight of the does due to treatments ranged between $-76.33 \mathrm{~g}$ to $-82.00 . \mathrm{g}$ vs.-69.00 $\mathrm{g}$ for the control diet. The negative weight gain observed during the lactating phase could be due to the mobilization of body reserve to synthesize milk for kids. These results were in agreement with Effiong et al. (2016) who found that rabbit does fed diets containing $60 \%$ orange pulp not significantly differ in their mean daily feed intake during gestation and lactation periods. However, Defang et al. (2012) observed that there were significant difference for feed consumption during lactation period. While, no significant difference for meeting weight, suckling weight and average weight gain during lactation period there were observed with rabbit fed diets containing $100 \%$ sweet potato concentrate meal instead of maize. In this respect, AL-Dobaib et al. (2009) found no significant differences in milk yield from goats does fed diet with $30 \%$ discarded dates. While, Milk obtained from does receiving discarded dates was 


\section{Salama et al.}

significantly higher in protein, solids-not-fat contents, casein nitrogen and non-casein nitrogen than those fed the control diet. El-Shora et al. (2014) found actual milk yield were higher $(\mathrm{P}<0.05)$ for cows fed $66 \%$ discarded dates than those fed the control. Cows fed $66 \%$ discarded dates recorded the highest $(\mathrm{P}<0.05)$ percentages of fat, protein, and total solids in milk. Increased milk yield with does receiving discarded dates may be due to potassium, glycine, and threonine content of dates that are thought to activate the production of milk hormone (prolactin). Small quantities of oxytocin have also been detected in dates and therefore dates can act as lactagogue if used in the daily meal plan of a woman during her lactation period (Ali et al. 2013).

Table (4). Performance traits of rabbit does as affected by different treatments during suckling period.

\begin{tabular}{|c|c|c|c|c|c|}
\hline \multirow{2}{*}{ Item } & \multirow{2}{*}{ Control } & \multicolumn{3}{|c|}{ Discarded dates $\%$} & \multirow[b]{2}{*}{ SEM } \\
\hline & & $25 \%$ & $50 \%$ & $75 \%$ & \\
\hline Total feed intake( $\mathrm{kg} /$ doe $)$ & 6.091 & 6.885 & 6.576 & 6.239 & 0.15 \\
\hline Daily feed intake $((\mathrm{kg} / \mathrm{doe})$ & 217.5 & 245.89 & 234.85 & 222.82 & 5.55 \\
\hline Mating weight $(\mathrm{g})$ doe & 2808.00 & 2833.00 & 2817.00 & 2851.00 & 20.10 \\
\hline Suckling weight (g) doe & 2739.00 & 2751.34 & 2734.67 & 2774.67 & 19.80 \\
\hline Change in weight (g) & -69.00 & -81.66 & -82.33 & -76.33 & 2.41 \\
\hline Total milk yield (kg/doe) & 2.08 & 2.38 & 2.25 & 2.17 & 0.09 \\
\hline
\end{tabular}

Difference within the same row were not significantly different ( $p \leq 0.05)$.

*Mating weight $(\mathrm{g})$ doe is live body weight at post partum.

**Suckling weight $)(\mathrm{g})$ doe is live body weight at the end of suckling period.

$* * *$ Change in weight $(g)=$ Suckling weight $(g)$ - Mating weight $(g)$.

\section{Productive traits of kids:}

Productive traits of kids as affected by different treatments are presented in Table 5. The litter weight at birth, total gain of litter, daily kids weight gain, total kids weight gain and mortality of kids were not affected by different treatments. However, Litter weight at birth and kid weight at weaning were significantly increased $(\mathrm{P} \leq 0.05)$ with rabbits fed diets containing $25 \%$ discarded dates and litter weight at weaning and kid weight at birth were significantly increased $(\mathrm{P} \leq 0.05)$ with rabbits fed diets containing 25 and $50 \%$ discarded dates. These results suggests that the discarded dates at levels 25, 50 and $75 \%$ provided sufficient amount of necessary nutrients of many potential health benefits that enabled the rabbits to produce quality milk for the kids (Iyeghe-Erakpotobor et al. 2008). These results were in agreement with those reported by Defang et al. (2012) who observed that litter weight at 21 days postpartum (milk yield) was significantly higher for does fed diet containing sweet potato concentrate meal. Also, they found that no significant difference in litter size at birth and litter size at weaning, litter weight at birth and at weaning. These results were in disagreement with Effiong et al. (2016) who found using orange pulp to replace of $60 \%$ instead of maize in rabbit does diets had significant higher litter size at birth and litter size at weaning. They found that average mortality ranged from $28.30 \%$ in rabbits fed $60 \%$ orange pulp to $34.25 \%$ for those fed control diet. The variation in average mortality was not significant. The authors observed an increase in litter size with higher levels of the fibrous digesta in the diets. The dietary fiber has positive effect on the gut health, welfare and reproductive performance of rabbit, especially during pregnant period. The observed in this current study improvement in reproductive performance for 25,50 and $75 \%$ discarded dates may be attributed to the higher unsaturated fatty acids in dates as presented by Al-Shahib and Marshall (2003) who found that the flesh of date contains $0.2-0.5 \%$ oil, and seeds contain $7.7-9.7 \%$ oil with high content of unsaturated fatty acids which including palmatic, oleic, linoleic and linolenic acids.

\section{Blood constituents:}

Data explain the effect of different levels of discarded dates on total protein, albumin, glucose, catalase, lipid Peroxides (Malondialdehyde) (MDA), alanine aminotransferase (ALT, aspartate and aminotransferase (AST) are shown in Table (6). Insignificantly could be noticed differences in concentration of plasma albumin, total protein, ALT and AST for rabbits fed different tested treatments compared to control group. 
However, catalase was significantly increased with rabbits fed diets containing discarded dates at levels 50 and $75 \%$ compared to those fed control diet. There were significantly decrease of glucose and lipid peroxides for rabbits fed on diets containing discarded dates at 75\%. In this respect, El-Shora et al. (2014) found that lactating Friesian Cows fed $66 \%$ discarded dates had the highest concentrations of total proteins, globulin,

Table (5). Productive traits of kids as affected by different treatments.

\begin{tabular}{llllll}
\hline \multirow{2}{*}{ Item } & \multirow{2}{*}{ Control } & \multicolumn{3}{c}{ Discarded dates \% } & \multirow{2}{*}{ SEM } \\
\cline { 3 - 5 } & & $25 \%$ & $50 \%$ & $75 \%$ & \\
\hline Litter size at birth (total born) & 7.24 & 7.97 & 7.74 & 7.55 & 0.35 \\
Litter size at birth (total alive) & 6.09 & 6.90 & 6.63 & 6.57 & 0.43 \\
Litter size at weaning & 4.30 & 5.04 & 4.80 & 4.63 & 0.39 \\
Litter weight at birth (g) & $345.54^{\mathrm{b}}$ & $464.33^{\mathrm{a}}$ & $418.63^{\mathrm{ab}}$ & $390.33^{\mathrm{ab}}$ & 16.25 \\
Litter weight at weaning (g) & $2220.0^{\mathrm{b}}$ & $2774.3^{\mathrm{a}}$ & $2612.7^{\mathrm{a}}$ & $2475.0^{\mathrm{ab}}$ & 78.15 \\
Total gain of litter (kg) / doe & 1.556 & 1.673 & 1.602 & 1.577 & 0.04 \\
Kids weight at birth (g) & $56.73^{\mathrm{b}}$ & $67.29^{\mathrm{a}}$ & $63.14^{\mathrm{a}}$ & $59.41^{\mathrm{b}}$ & 1.26 \\
Kids weight at weaning (g) (28 day) & $516.27^{\mathrm{b}}$ & $550.36^{\mathrm{a}}$ & $544.31^{\mathrm{ab}}$ & $534.55^{\mathrm{ab}}$ & 5.45 \\
Kids weight gain (daily) (g) & 16.41 & 17.25 & 17.18 & 16.96 & 0.29 \\
Kids weight gain (Total) (g) & 459.54 & 483.06 & 481.17 & 475.14 & 21.01 \\
Mortality \% of kids (from birth till & 29.39 & 26.95 & 27.60 & 29.52 & 0.65 \\
weaning) & & & & & \\
\hline
\end{tabular}

a,b--- Means in the same row with different superscripts are significantly different $(P<0.05)$.

Table (6). Blood constituents of rabbits does fed different experimental diets.

\begin{tabular}{|c|c|c|c|c|c|c|}
\hline \multirow{2}{*}{\multicolumn{2}{|c|}{ Item }} & \multirow{2}{*}{ Control } & \multicolumn{3}{|c|}{ Discarded dates $\%$} & \multirow[b]{2}{*}{ SEM } \\
\hline & & & $25 \%$ & $50 \%$ & $75 \%$ & \\
\hline Glucose mmol/l & & $74.14^{\mathrm{a}}$ & $70.12^{\mathrm{ab}}$ & $68.68^{\mathrm{ab}}$ & $66.19^{b}$ & 1.21 \\
\hline Total protein, g/dl & & 5.00 & 5.27 & 5.59 & 5.62 & 0.11 \\
\hline Albumin, g/dl & & 3.55 & 3.57 & 3.89 & 3.93 & 0.06 \\
\hline AST(U/L) & & 54.10 & 52.92 & 47.14 & 44.02 & 1.80 \\
\hline $\operatorname{ALT}(\mathrm{U} / \mathrm{L})$ & & 60.76 & 57.13 & 57.13 & 52.83 & 1.92 \\
\hline $\begin{array}{l}\text { Lipid Peroxides } \\
\text { (Malondialdehyde) (MDA) }\end{array}$ & $\mathrm{nmol} / \mathrm{ml}$ & $9.11^{\mathrm{a}}$ & $8.36^{\mathrm{ab}}$ & $8.33^{\mathrm{ab}}$ & $7.76^{\mathrm{b}}$ & 0.18 \\
\hline Catalase (U /l) & & $744.96^{\mathrm{b}}$ & $756.66^{\mathrm{b}}$ & $777.33^{\mathrm{a}}$ & $786.73^{\mathrm{a}}$ & 5.52 \\
\hline
\end{tabular}

$a, b---$ Means in the same row with different superscripts are significantly different $(P<0.05)$.

glucose and the lowest concentrations of albumin and total lipids in blood plasma. The obtained results are in agreement with those reported by AL-Dobaib et al. (2007) who found that total proteins, albumin, globulin, total lipids, were not differ for rabbits fed diets containing 15 and $30 \%$ of discarded dates while, significant decrease in cholesterol level was observed for rabbits fed diet containing $30 \%$ discarded dates. Also, Olorede and Longe (2000) found that there were no significant difference $(\mathrm{p}<0.05)$ in total protein, Albumin while, there were significant decrease in concentration of glucose in blood plasma of laying hens fed 10 and 20\% palm kernel cake. In contrary, Abdel-Fattah et al. (2012) found that partial substitution of ground yellow corn in concentrate feed mixture with ground date palm at $50 \%$ weight by weight slightly increased $(\mathrm{P}<0.01)$ blood total protein than control group of growing Barki lambs. Increasing of catalase and decreasing of lipid peroxides may be due to that dates containing an antioxidant substance. This interpretation is in accordance with Amoros et al. (2009) who reported that palm date and its fibers have several nutritional values such as antioxidant activity. The antioxidant activity could be due to its lignin content in dates, since lignin has been shown to possess an antioxidant and antimicrobial activities (Brunow, 2006).

\section{Progesterone hormone, total trioiodothyronine $\left(\mathrm{T}_{3}\right)$ and total thyroxin $\left(\mathrm{T}_{4}\right)$}

Results of progesterone, total trioiodothyronine $\left(\mathrm{T}_{3}\right)$ and total thyroxin $\left(\mathrm{T}_{4}\right)$ values as affected by different treatment are shown in Table (7). Results indicated that progesterone hormone were 


\section{Salama et al.}

significantly increased for rabbits fed diets containing $25 \%$ discarded dates. Also, total trioiodothyronine $\left(\mathrm{T}_{3}\right)$ were significantly increased with rabbits fed diets containing 25 and $50 \%$ discarded dates. However, total thyroxin $\left(\mathrm{T}_{4}\right)$ was not affected by different treatments. Hashem (2014) stated that rams fed $50 \%$ ground discarded dates in concentrate feed mixture had significant effect on $\mathrm{T}_{3}$ and $\mathrm{T}_{4}$ compared with control rams. Similar results were reported by Abdel-Fattah et al. (2012) on Barki lambs which fed ground date palm at Siwa Oasis appeared to have a positive correlation between thyroid hormones $\left(\mathrm{T}_{3}\right.$ and $\left.\mathrm{T}_{4}\right)$ and both the age of animal and body weight gain $(\mathrm{P}<0.01)$. Also, Mousa and Al-Saiady $(2002)$ found that there was a positive correlation between thyroid hormones levels in serum and body weight during the growing period of Somali camels fed different levels of commercial feeds. The presence of steroid compounds in date pits, notably estrone, progesterone and estriol, had been known, though the actual effects of these compounds on sheep growth and reproduction have yet to be clearly demonstrated (Barreveld, 1993; El-Gasim et al., 1995, El-Din and El-Hameed, 2001). Date palm pollen grains have been shown to regulate the sexual hormonal balance in rats (Reshod and Al-Shagrawi, 1998). The date pollens yield an estrogenic principle, estrone that has been shown to have a gonadotropic effect in young rats (El-Moughy et al. 1991).

Table (7). Progesterone, total trioiodothyronine $\left(T_{3}\right)$ and total thyroxin $\left(T_{4}\right)$ as affected by different treatments.

\begin{tabular}{llllll}
\hline \multirow{2}{*}{ Item } & \multirow{2}{*}{ Control } & \multicolumn{3}{c}{ Discarded dates \% } \\
\cline { 3 - 5 } & & $25 \%$ & $50 \%$ & $75 \%$ & SEM \\
\hline Progesterone $(\mathrm{ng} / \mathrm{ml})$ & $0.676^{\mathrm{b}}$ & $0.935^{\mathrm{a}}$ & $0.828^{\mathrm{ab}}$ & $0.743^{\mathrm{ab}}$ & 0.039 \\
$\mathrm{~T}_{3}(\mathrm{ng} / \mathrm{ml})$ & $0.45^{\mathrm{b}}$ & $0.70^{\mathrm{a}}$ & $0.65^{\mathrm{a}}$ & $0.49^{\mathrm{b}}$ & 0.020 \\
$\mathrm{~T}_{4}(\mathrm{ng} / \mathrm{ml})$ & 5.24 & 6.34 & 5.85 & 5.68 & 0.31 \\
\hline
\end{tabular}

$\boldsymbol{a}, \boldsymbol{b}---$ Means in the same row with different superscripts are significantly different $(P<0.05)$.

\section{Economic efficiency:}

The economical efficiency of the different formulated diets as affected by different treatments is shown in Table 8. The economical efficiency of the present study was calculated based upon input-output analysis of the total feeding cost/doe and the prevailing selling price of the litter/doe at weaning. The results indicated that the lowest total feed cost /doe (LE) (27.35 LE) was observed with rabbits fed the diets containing $75 \%$ discarded dates followed by those fed 50\% discarded dates (30.59 LE). Results indicated that group fed the diets contained $75 \%$ discarded dates achieved the highest economical efficiency (1.3700) followed by diets contained $50 \%$ discarded dates (1.196). The corresponding values of relative economical efficiency of diets contained $75 \%$ and $50 \%$ discarded dates were (175.88) and (153.54), respectively.

Generally, The results of this study demonstrate that discarded dates can be used as a replacement for barely grains in rabbit diets at levels 50 and $75 \%$. Moreover, the $75 \%$ had the best economical return over other treatments one. These results are in agreement with Khattab (2013) who found that replacement of corn grain with $100 \%$ dates can reduce the cost of concentrate mixture components of lactating ewes diet by about 24\%. Also, El-Shora et al. (2014) reported that lactating Friesian cows fed 66\% discarded dates showed the lowest feed cost/ $\mathrm{kg}$ and the best economical efficiency followed by those fed $100 \%$ discarded dates compared with control group.

It could be noticed that using discarded dates as a source of energy to replace barely grains in rabbit does ration tended to improve reproductive performance. This may be due to date palm possesses several highly beneficial properties such as antiviral, antifungal, antioxidant, antihyperlidimic activity and hepatoprotective activity (Al-Farsi and Lee, 2008). These are attributed to the rich contents of antioxidants in date fruit such as the coumaric acid and ferulic acid. Moreover, it contains flavonoids, sterols, procyanidins, carotenoids, anthocyanins, sugar (glucose, sucrose and fructose), dietary fibers, less protein and fats, vitamins such as riboflavin, biotin, thiamine, ascorbic and folic acids, and minerals for example calcium, iron, copper, cobalt magnesium, fluorine, manganese, phosphorus, potassium, sodium, boron, sulfur, zinc and selenium within the date palm (Anjum et al. 2012). 
Egyptian J. Nutrition and Feeds (2016)

Table (8). Effect of discarded dates on economical efficiency of rabbit does.

\begin{tabular}{|c|c|c|c|c|}
\hline \multirow{2}{*}{ Item } & \multirow{2}{*}{ Control } & \multicolumn{3}{|c|}{ Discarded dates } \\
\hline & & $25 \%$ & $50 \%$ & $75 \%$ \\
\hline Price $/ \mathrm{kg}$ diet & 3.14 & 2.72 & 2.58 & 2.46 \\
\hline $\begin{array}{l}\text { Total feed consumed doe/gestation } \\
\text { period } / \mathrm{kg}\end{array}$ & 4.688 & 5.320 & 5.283 & 4.880 \\
\hline $\begin{array}{l}\text { Total feed consumed doe/suckling } \\
\text { period } / \mathrm{kg}\end{array}$ & 6.091 & 6.885 & 6.576 & 6.239 \\
\hline Total feed cost /doe (LE) & 33.84 & 33.19 & 30.59 & 27.35 \\
\hline Litter size at weaning & 4.30 & 5.04 & 4.80 & 4.63 \\
\hline $\begin{array}{l}\text { Total revenue/ Litter at weaning } \\
(\mathrm{LE})^{1}\end{array}$ & 60.20 & 70.56 & 67.20 & 64.82 \\
\hline Net revenue/doe $(\mathrm{LE})^{2}$ & 26.36 & 37.37 & 36.61 & 37.47 \\
\hline Economical efficiency (LE) ${ }^{3}$ & 0.7789 & 1.1259 & 1.196 & 1.370 \\
\hline Relative economical efficiency & 100 & 144.55 & 153.54 & 175.88 \\
\hline
\end{tabular}

${ }^{I}$ Total revenue $=$ Litter size $x 14$, assuming that the selling price of each rabbit at weaning was LE (14).

${ }^{2}$ Net revenue/ rabbit doe $(L E)=$ Total revenue/ Litter at weaning-Total feed cost / rabbit doe.

${ }^{3}$ Economic efficiency $=$ Net revenue/ rabbit doe/ Total feed cost $/$ rabbit doe (LE).

\section{CONCLUSION}

It is concluded that discarded dates is a good sources of energy for breeding rabbit does. Does fed diets containing discarded dates at levels 25, 50 and $75 \%$ had better reproductive performance and economical efficiency compared with control diets. Moreover, using $75 \%$ discarded dates had the best net revenue, economical and relative economical efficiency.

\section{REFERENCES}

Abdel-Fattah, M.S.; Afaf, A. Abdel-Hamid; Ashgan, M. Ellamie; M.M. El-Sherief and M.S. Zedan (2012). Growth Rate, Some plasma biochemical and amino acid concentration of Barki lambs fed ground date palm at Siwa Oasis, Egypt. American-Eurasian J.Agric.\& Environ. Sci., 12(9): 11661175.

Abdel-Rahman, H. H.; A. A. Abedo; Y. A. A. El Nomeary; M. M. Shukry; M. I. Mohamed and M. S. Zaki (2012). Response of re-placement of yellow corn with cull dates as a source of energy on productive performance of goat kids. Life Sci. J., 9(4), 2250-2255.

Aebi, H. (1984). Catalase inVitro. Method Enzyme, 105: 121-126.

Al-Dobaib, S.N.; M.H. Khalil; M. Hashad and A.M. Al-Saef (2007). Growth, Carcass and ceacal traits in V- Line and crossbred rabbits fed diets containing discarded dates. World Rabbit Sci., 15: 81- 90.

Al-Dobaib, S.N.; M.A. Mehaia and M.H. Khalil (2009). Effect of feeding discarded dates on milk yield and composition of Aradigoats. Small Ruminant Research 81: 167-170.

Al-Farsi, M.A. and C.Y. Lee (2008). Nutritional and functional properties of dates: a review. Crit. Rev. Food Sci. Nutr. 48: 877-887.

Ajayi, F.O.; O.O. Balogun.; S.S. Ovuru and O.O. Mgbere (2005). Reproductive performance of rabbits fed maize-milling waste based diets African Journal of Biotechnology. Vol. 4 (5): 439-443.

Ali, A.; M. Waly; M. M. Essa and S. Devarajan (2013). Nutritional and medicinal value of data fruit. Dates: Production, Processing, Food, and Medicinal Values. (26): 361-371.

Alkhateeb, A.A. and H.M. Ali-Dinar (2001). Date palm (phoenix dactylifera L.) production and research in Kingdom of Saudi Arabia. The date palm International Symposium, Windhoek, Nambia. 


\section{Salama et al.}

Al-Shahib, W. and R.J. Marshall (2003). The fruit of the date palm: its possible use the best food for the future?. International J. Food Sciences and Nutrition, (54): 247-259.

Al-Yousef, Y.M.; F.N. Al-Mulhim; G.A. El-Hag and G.A. Al-Gasim (1994). Apparent digestibility of discarded dates and date pits together with other agricultural by-products. Annals Agric.Sci., Ain Shams Univ., 39(2): 655-662.

Amoros, A.; M.T.Pretel; M.S. Almansa; M.A. Botella; P.J. Zapata and M. Serrano (2009). Antioxidant and nutritional properties of date fruit from elche grove as affected by maturation and phenotypic variability of date palm. Food Sci. Technol. Int. 15: 65-72.

Anjum F.M.; S.I. Bukhat; A.H. El-Ghorab; M.I. Khan and M. Nadeem (2012). Phytochemical characteristics of date palm (Phoenix dactylifera) fruit extracts. Pak. J. Food Sci., 22: 117- 127.

A.O.A.C. (2000).Official methods of analysis. $17^{\text {th }}$ ed., published by the A.O.A.C., Washington, D.C., USA.

Barker, F.S. and R.E. Silverton (1982). Introduction to Medical Laboratory Technology. 5th Ed. Publ. Butterworth S.C London, pp: 481-494.

Barreveld, W.H. (1993). Date palm products. Food and Agriculture Organization Agricultural Services, Bulletin No. 101.

Bojanic, S.; R. Lake; J. Place; L. Jones; J. Laycoock; G. Carter and J. Alagh-Band-zadeh (1991). Serum progesterone concentration is raised during early follicular phase in women with polycystic ovaries. Ann. Clin. Biochem., 28: 105-106.

Brunow, G. (2006). In Biorefineries-Industrial Processes and Products; Kamm, B., Gruber, P.R., Kamm, M., Ed.; WILEY-VCH Verlag GmbH \& Co. KGaA: Weinheim, Gernany, 2 (4), 151-163.

Castellini C.; A. Dal Bosco and C. Mugnai (2003). Comparison of different reproductive protocol for rabbit does: effect of litter size and mating interval livestock production science 83:131-139.

Cheeke, P.R. (1982). High roughage diets utilization by rabbits. Feed International. 3,46-51.

Cheeke, P. R. (1987). Rabbit Feeding and Nutrition. Academic Press, Orlando, Florida USA. 376p.

Defang, H. F. 1.; J.R.1.; Kana; F.1. Ngoula; T. C Keambou; A.1. Teguia and N. Emene (2012). Reproductive performance of local rabbit does on sweet potato concentrate meal to forage combination under tropical condition. Wayamba Journal of Animal Science University- ISSN 2012578X, 647-653.

Doumas, B.T. and W. Waston (1971). Albuminstandards and measurement of plasma albumin withbromocresol green. Clin. Chem. Acta.,31,87.

Duncan, D.B. (1955). Multiple Range and Multiple F-Test. Biometrics, 11:1-42.

Effiong, O. O.; L. E. Asuquo and B. E. Atiata (2016). Reproductive Performance of Breeder Rabbits Fed Diets with Graded Levels of Orange Pulp Meal as energy source American Journal of Experimental Agriculture, 10(6): 1-6.

El-Din, A.E.M and A.K.E.A. El-Hameed (2001). Study on the preparation of date seeds for animal feeding. 2nd Inter. Conf. on Date Palms. March 25-27, Al-Ain, United Arab Emirates Univ., pp. 887898.

El-Gasim, E.A.; Y.A. Al-Yousef and A.M. Humeida (1995). Possible hormonal activity of date pits and flesh fed to meat animals. Food Chem., 52: 149-152.

El-Moughy, S.A.; S.A. Abdel-Aziz; M. Al-Shanawany and A. Omar (1991). The gonadotropic activity of palmae in mature rats. Alexandria Journal of Pharmaceutical Research 5: 156-159.

El-Shora, M.A.; M.H. Abo El-Fadel; T.A. Deraz and Y.M. El-Diahy (2014). Effect of using discarded dates on productive and reproductive performance of lactating cows. J. Animal and Poultry Prod., Mansoura Univ., Vol. 5 (12): 775 - 789.

FAO (2011). Food and Agriculture Organization of the United Nations.

Gornal A. G.; C. J. Bardawill and M. M. Divid (1949). Determination of plasma protein by means of the biurent reaction. J. Biol.Chem.,177, 751. 
Hashem, A.L.S. (2014). Semen Physical Traits and Thyroid Activity of Barki Rams as Affected by Season and Feeding Non-Edible Date Palm at Siwa Oasis, Egypt. World Applied Sciences Journal 30 (5): 556-566, 2014

Khan, M.; A. Sarwar; M. Wahab and R. Haleem (2008). Physio-chemical characterization of date varieties using multivariate analysis. Journal of Food Agriculture 88: 1051-1059.

Iyeghe-Erakpotobor, G.T.; Y.G. Adeosun; A.A. Sekoni and L.O. Esievo (2008). Reproductive performance of rabbit does on concentrate to forage (Stylosanthes hamata) combinations. Livestock Res. for Rural Dev.;20(11).

Khattab, I. M. (2013). Effect of replacing corn grain with dates to lactating ewes on milk production and growth rate of their lambs. Egypt J. Nutr. and feeds, 16(2): 219-224.

McNitt, J.I. and D. Lukefahr (1990). Effect of breed, parity and days of lactation of rabbits. J. Anim. Sci., 68:1505-1512.

Mousa, I.A. and M.Y. Al-Saiady (2002). Thyroid hormones levels in growing male camels fed different levels of commercial feeds. J. King. Saud. Univ., Agric. Sci., 14(2): 71-76.

NRC (1977). National Research Council. Nutrient requirements of rabbits. Nat. Acad. Sci., Washington, DC.

Olorede, B.R. and O.G. Longe (2000). Effect of replacement kernel cake with sheabutter cake on egg quality characteristics, hematology and serum chemistry of laying hens. Nigerian J. of Animal Production 27(1) 19-23.

Reitman, S. and Frankel, S. (1957). Determination of GOT and GPT Amr. J. Clin. Path., 28:56-63.

Reshod, A. and M. Al-Shagrawi (1998). Enzyme activities, lipid functions, and fatty acid composition in male rat fed palm pollen grains (Phoenix dactylifera). Research Bulletin, 79: 5-18.

SAS, (2004). User's guide. Statistic. SAS Inst. Cary, N.C. Releigh

Satoh, K. (1978). Serum lipid peroxide in cerebro vascular disorders determined by a new colorimetric method. Clin. Chim. Acta. 15;90 (1): 37-43.

Sawaya, W. N.; J. K. Khalil and W. J. Safi (1983). Chemical composition and nutritional quality of date seeds. J. Food Sci., 49: 617-619.

Soliman, A.Z.M.; M.A.F. El-Manylawi; Fatma G. Ahmed; Fatma T.F. Abd- El Ghany (2012). Reproductive performance of New Zealand white rabbit does fed on diets containing corn distiller's dried grains with soluble. $3^{\text {rd }}$ Mediterranean Poultry Summit and $6^{\text {th }}$ International Poultry Conference, 26 -29 March, Alexandria, Egypt.

Trinder, P. (1969). Determination of blood glucose using an oxidase-peroxidase system with a noncarcinogenic chromogen. J .Clin Pathol. 22(2):158-161.

Wattanapenailboon, N and M. Wahlqvist (2003). Phytonutrient deficiency : the place of palm fruit. Asia Pacific J Clin Nutr; 12(3): 363-368.

Zarrouki, N.; G. Bolet; M. Berchiche and F. Lebas (2004). Breeding performance of local Kabylian rabbits in Algeria . proceedings of the 8th world rabbit congress, September 7-10 pueblo, Mexico. 
تأثير إستبدال حبوب الثعير بالبلح الفرز على الأداء التناسلى لأمهات الأرانب النيوزلاندى الأبيض.

ولاء عطيه سلامه و مروه عبد المنعم سليمان و محمد احمد الثورى و عطية إبراهيم عبد اللطيف

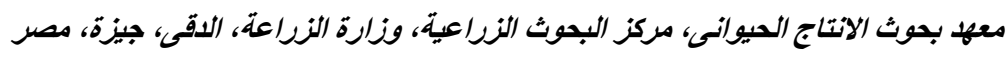

صمم هذا البحث لدراسة الأداء التناسلى لأمهات الأر انب المغذاة على مستويات مختلفة من البلح الفرز.فى البداية تم تجميع البلح الفرز

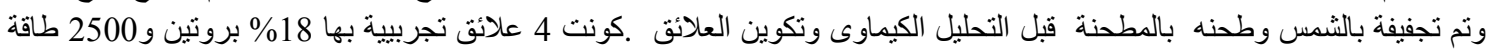

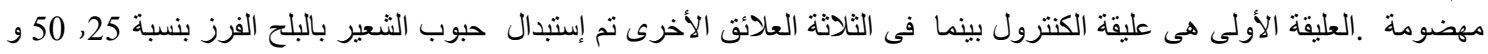

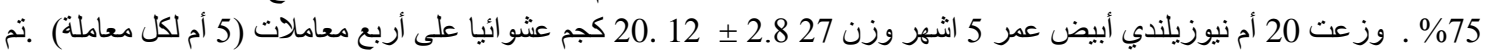

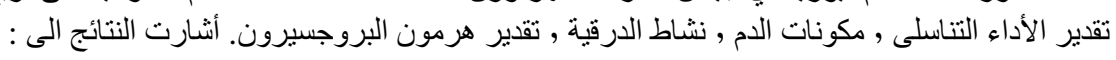

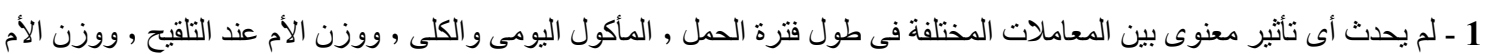

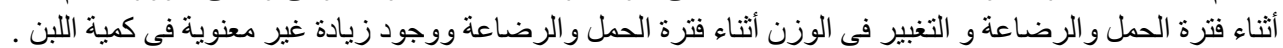

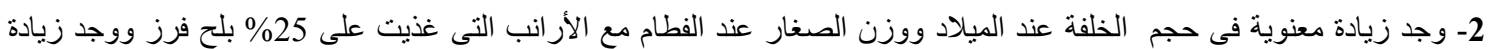

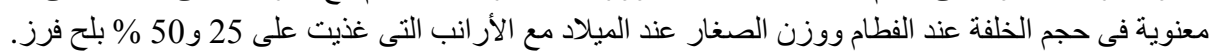

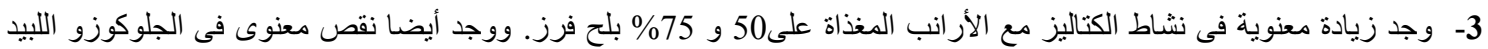
بيروكسيد مع التغذية على 75\% بلح فرز بالئ بالمقارنة بمجمو عة الكنترول .

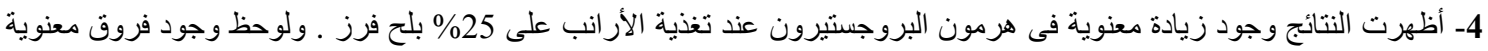

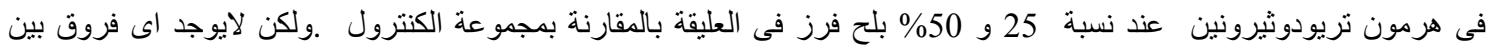
المعاملات المختلفة فى هرمون الثيروكسين.

5ـ أظهرت النتائج ان المجو عة التى غذيت على 75 \% بلح فرز أعلى كفاءة إقتصادية يليها المجو عة التى غذيت على 50\% بلح فر فرز

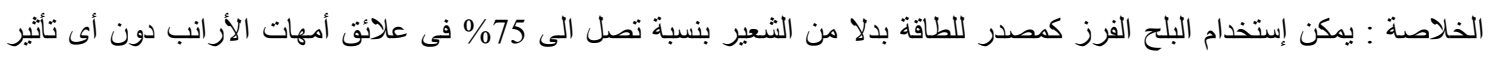
جانبى على الكفاءة التناسلية. 